\title{
UPAYA MENINGKATKAN HASIL BELAJAR IPA SISWA KELAS IV MENGGUNAKAN MODEL PEMBELAJARAN KOOPERATIF TIPE STAD
}

\author{
Hasrat \\ Guru Sekolah Dasar Negeri 05 Rantau Alai \\ Desa Lebung Bandung Kecamatan Rantau Alai \\ Kabupaten Ogan Ilir Sumatera Selatan \\ Sur-el: hasratdoank@gmail.com
}

\section{Article info}

Article history:

Received: 08/11/2019

Revised : $15 / 11 / 2019$

Accepted: 15/12/2019
Keywords:

Classroom Action

Research (CAR),

STAD, Learning

Outcomes of Science

Kata Kunci:

Penelitian Tindakan

Kelas (PTK), STAD,

Hasil Belajar IPA

\begin{abstract}
A B S T R A C T
The purpose of this study is to describe the efforts in improving science learning outcomes using the cooperative learning model type Student Teams Achievement Divisions (STAD) in class IV students of SDN 05 Rantau Alai. The method used in this research is Classroom Action Research (CAR). In accordance with the Classroom Action Research (CAR) model, the research procedure consists of 4 stages, namely: (1) planning, (2) implementation, (3) observation, (4) reflection. This research consisted of pre-cycle, first cycle and second cycle. The results of this study indicate an increase in science learning outcomes for fourth grade students of SDN 05 Rantau Alai. This can be seen from the results of cycle I to cycle II, from a $60 \%$ percentage increase to $90 \%$ with the good group category.
\end{abstract}

Tujuan dari penelitian ini yaitu mendeskripsikan upaya-upaya dalam meningkatkan hasil belajar IPA menggunakan model pembelajaran kooperatif tipe Student Teams Achievement Divisions(STAD)pada Siswa Kelas IV SD Negeri 05 Rantau Alai. Metode yang dipakai dalam penelitian ini adalah Penelitian Tindakan Kelas (PTK). Sesuai dengan model Penelitian Tindakan Kelas (PTK), prosedur penelitian terdiri dari4 tahap, yaitu: (1) perencanaan, (2) pelaksanaan, (3) pengamatan, (4) refleksi. Penelitian ini terdiri dari pra-siklus, siklus I dan siklus II. Hasil penelitian ini menunjukkan peningkatan hasil belajar IPA siswa kelas IV SDN 05 Rantau Alai. Hal ini dapat dilihat dari hasil siklus I ke siklus II yaitu dari presentase $60 \%$ meningkat menjadi $90 \%$ dengan kategori kelompok baik.

DirektoratRisetdanPengabdianMasyarakat UniversitasBinaDarma. 


\section{PENDAHULUAN}

Kurikulum 2013 erat kaitannya dengan tematik. Adapun karakteristik pembelajaran tematik yaitu (1) berpusat pada siswa, (2) memberikan pengalaman langsung kepada siswa, (3) pemisahan mata pelajaran tidak begitu jelas, (4) menyajikan konsep dari berbagai mata pelajaran dalam suatu proses pembelajaran, (5) bersifat fleksibel, (6) hasil pembelajaran dapat berkembang sesuai minat dan kebutuhan siswa.Di era globalisasi yang kita hadapi saat ini pesatnya perkembangan Ilmu Pengetahuan dan Teknologi (IPTEK), sehingga menuntut pengembangan kemampuan siswa sekolah dasar dalam bidang Ilmu Pengetahuan Alam (IPA). Namun kenyataan di lapangan menunjukkan hasil belajar IPA masih tergolong rendah. Hal tersebut sejalan dengan penelitian Febriyanto (2011) yang menyatakan bahwa pembelajaran IPA masih terpusat pada guru sehingga menyebabkan rendahnya aktivitas serta hasil belajar IPA di SD.

Proses belajar dengan penyampaian yang kurang tepat yakni ceramah. Pendekatan tersebut kurang memberikan kesempatan kepada peserta didik untuk melakukan kegiatannya sendiri dan kerja sama dengan teman dalam mengamati objek yang dipelajarinya. Pembelajaran diartikan sebagai proses interaksi peserta didik dengan pendidik dan sumber belajar pada suatu lingkungan belajar (Susanto, 2013).Dalam penyampaian materi, guru cenderung monoton menguasai kelas sehingga peserta didik kurang leluasa untuk bertanya dan memaparkan ide-idenya. Akibatnya hasil belajar IPA menjadi kurang optimal. Nurjanah (2016) dalam penelitiannya juga menjelaskan bahwa penyebab rendahnya hasil belajar IPA siswa diantaranya (1) faktor guru, dimana metode yang diterapkan dalam proses belajar mengajar lebih didominasi oleh guru sehingga siswa kurang dilibatkan secara aktif dalam proses ini, (2) faktor siswa, siswa cenderung merasa bosan dikarenakan dalam pembelajaran siswa bersifat pasif, hanya menerima apa yang disampaikan guru.

Guna menanggulangi permasalahan di atas, salah satu pendekatan yang dapat melibatkan siswa secara maksimal yaitu model pembelajaran kooperatif tipe STAD (Student Team Achievement Divisions). Pendekatan ini dapat meningkatkan hasil belajar siswa dan mengurangi kelemahan-kelemahan dalam pembelajaran IPA yang berkaitan dengan hasil belajar. Hal ini sejalan dengan Zainuddin (2002) yang menyatakan bahwa peningkatan pada skor tes yang signifikan didapat karena penerapan metode STAD (Student Team Achievement Divisions) dalam pembelajaran. Pembelajaran kooperatif menurut Slavin (2015) yaitu pembelajaran yang mengajak siswa untuk berkelompok dan bekerja sama dengan anggota kelompok untuk 


\section{JURNALILMIAH}

BINAEDUKASI

ISSN 1979-8598E-ISSN: 2655-8378

http://journal.binadarma.ac.id/index.php/jurnalbinaedukasi

Vol. 12, No. 2, Desember 2019, 31 -- 41

menguasai materi yang dipelajari. Pernyataan ini senada dengan Shoimin (2016) yang mengungkapkan bahwa pembelajaran secara kooperatif berarti bekerja sama dalam mengkonstruksi konsep serta menyelesaikan masalah yang dihadapi. Hal ini menunjukkan bahwa pendekatan pembelajaran yang kooperatif memang diperlukan untuk meningkatkan hasil belajar siswa. Adapun tujuan dari penelitian ini adalah mendeskripsikan upaya-upaya dalam meningkatkan hasil belajar IPA menggunakan model pembelajaran kooperatif tipe Student Teams Achievement Divisions(STAD)Pada Siswa Kelas IV SD Negeri 05 Rantau Alai.

\section{METODOLOGI PENELITIAN}

\subsection{Metode Penelitian}

Adapun jenis penelitian yang dilakukan oleh penelitian ini adalah Penelitian Tindakan Kelas (PTK) yang dalam bahasa Inggris PTK disebut Classroom Active Research (CAR). Penelitian tindakan kelas berasal dari tiga kata yaitu penelitian, tindakan, dan kelas (Aqib, 2009). Penelitian diartikan sebagai kegiatan mencermati suatu objek, menggunakan aturan metodologi tertentu untuk memperoleh data atau informasi yang bermanfaat untuk meningkatkan mutu dari suatu hal yang menarik minat dan penting bagi penelitian.Tindakan diartikan sebagai suatu gerak kegiatan yang sengaja dilakukan dengan tujuan tertentu, yang dalam penelitian ini berbentuk siklus kegiatan. Kelas diartikan sebagai sekelompok siswa yang dalam waktu yang sama menerima pelajaran yang sama dari seorang guru. Menggabungkan tiga kata tersebut maka penelitian tindakan kelas adalah suatu pencermatan terhadap kegiatan yang sengaja dimunculkan, tetapi dalam sebuah kelas.

Adapun karakteristik dari PTK menurut Sukardi (2007) adalah (1) problem yang dipecahkan merupakan persoalan yang dihadapi peneliti dalam kehidupan sehari-hari, (2) peneliti memberikan perlakuan yang terencana untuk memecahkan permasalahan, (3) langakahlangkah penelitian yang direncanakan selalu dalam bentuk siklus, tingkatan atau daur yang memungkinkan terjadi kerja kelompok maupun kerja mandiri secara intensif, (4) adanya langkah berpikir reflektif dari peneliti baik sesudah maupun sebelum tindakan. Sedangkan menurut Soedarsono (2001) karakteristik PTK meliputi Situasional, artinya berkaitan langsung dengan permasalahan, konkret yang dihadapi guru dan siswa di kelas. Kontekstual, artinya upaya pemecahan yang berupa model dan prosedur tindakan tidak lepas dari konteksnya. Kolaboratif, artinya partisipasi, antara guru—siswa dan mungkin asisten yang membantu proses pembelajaran. Self - reflective dan Self-evaluative, artinya pelaksana, pelaku tindakan serta objek yangh dikenai tindakan melakukan refleksi dan evaluasi diri terhadap hasil atau kemajuan yang dicapai. Fleksibel, artinya memberikan sedikit kelonggaran 


\section{JURNALILMIAH}

BINAEDUKASI

ISSN 1979-8598E-ISSN: 2655-8378

http://journal.binadarma.ac.id/index.php/jurnalbinaedukasi

Vol. 12, No. 2, Desember 2019, 31 -- 41

dalam pelaksanaan tanpa melanggar kaidah metodologi ilmiah.Sesuai dengan model Penelitian Tindakan Kelas (PTK), prosedur penelitian terdiri dari 4 tahap, yaitu: (1) perencanaan, (2) pelaksanaan, (3) pengamatan, (4) refleksi, siklus dalam penelitian ini digambarkan sebagai berikut.

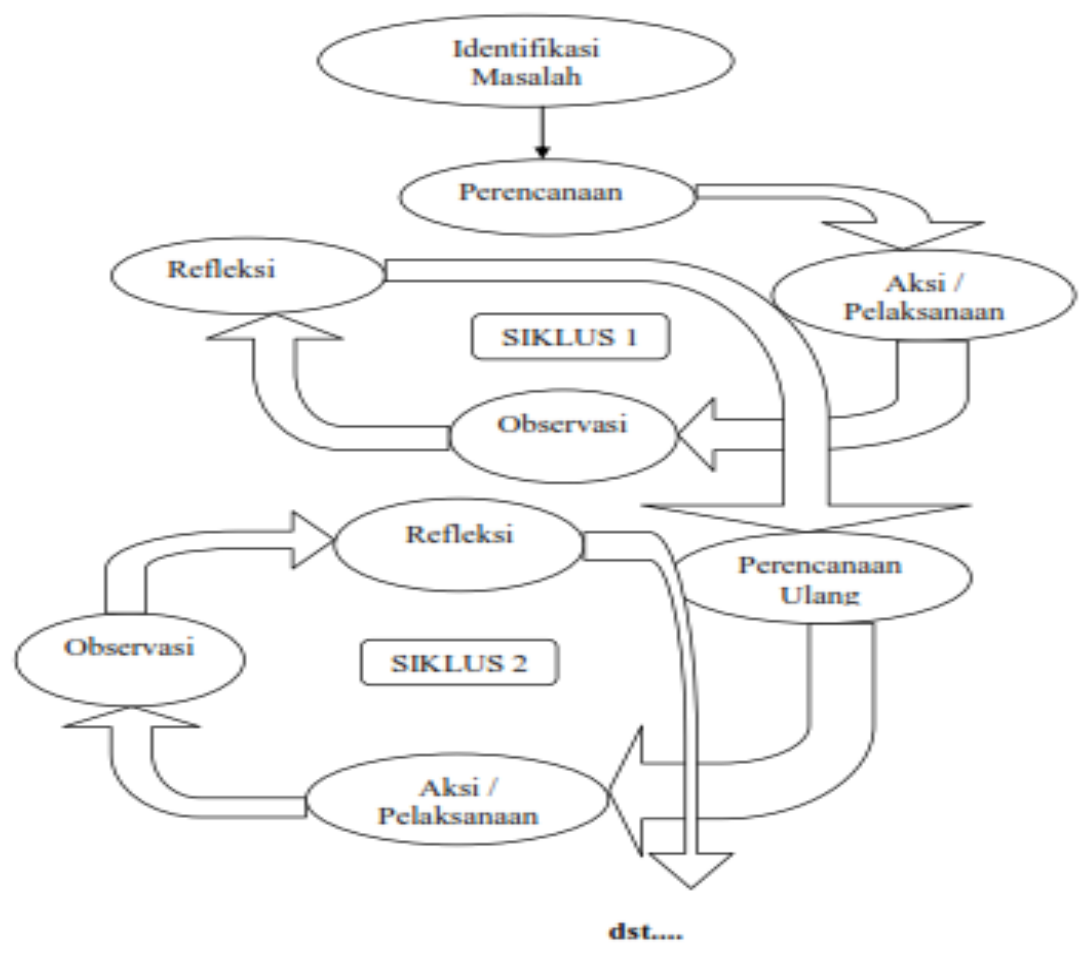

Gambar 1. Spiral Tindakan Kelas (Hopkins, dalam Zainal Aqib, 2009)

\subsection{Tempat Pelaksanaan Penelitian}

Penelitian ini dilaksanakan pada bulan Agustus tahun 2019. Tempat penelitian adalah tempat yang digunakan dalam melakukan penelitian untuk memperoleh data yang diinginkan. Penelitian ini dilaksanakan di SD Negeri 05 Rantau Alai tahun ajaran 2019/2020.

\subsection{Subjek Penelitian}

Subjek dalam penelitian ini adalah siswa kelas IV SD Negeri 05 Rantau Alai dengan jumlah 20 orang siswa. Subjek penelitian terdiri dari sebelas siswa perempuan dan sembilan siswa laki-laki. Pemilihan kelas IV sebagai subjek penelitian karena siswa kelas IV memiliki tingkatan kecerdasan yang berbeda-beda atau heterogen, mengingat kelas IV ini merupakan kelas reguler biasa artinya bukan kelas unggulan ataupun kelas pilihan. Oleh sebab itu, peneliti menjadikan siswa kelas IV sebagai subjek penelitian.Objek dalam Penelitian Tindakan Kelas 


\section{JURNALILMIAH}

BINAEDUKASI

ISSN 1979-8598E-ISSN: 2655-8378

http://journal.binadarma.ac.id/index.php/jurnalbinaedukasi

Vol. 12, No. 2, Desember 2019, 31 -- 41

yang diteliti mencakup: (1) variabel tindakan berupa pembelajaran yang menggunakan model kooperatif tipe $S T A D$ dan (2) variabel dampak berupa hasil belajar IPA siswa.

\subsection{TeknikPengumpulan Data}

Teknik pengumpulan data yang digunakan dalam penelitian ini adalah teknik tes dan nontes.Teknik tes digunakan dengan memberikan pretes kepada subjek penelitian sebelum menerapkan metode pembelajaran STAD.Pretes terdiri dari sepuluh soal. Kemudian, postes dilakukan setiap akhir siklus untuk melihat peningkatan hasil belajar menggunakan metode $S T A D$.

\subsection{TeknikAnalisis Data}

Data yang dikumpulkan menggunakan teknik tes baik pretes maupun postes merupakan data kuantitatif. Data kuantitatif diperoleh dengan menghitung nilai rata-rata kelas dari hasil pretes, dan postes di setiap siklus yang diberikan kepada siswa. Nilai rata-rata kelas dianalisis menggunakan rumus berikut.

$\bar{X}=\frac{\sum x}{n}$

Keterangan:

$\bar{X} \quad$ : Nilai rata-rata kelas

$\sum x \quad$ : Jumlah nilai siswa

n : banyaknyasiswa (Suharsimi, 2010)

Pada tahap refleksi, dilakukan penentuan persentase ketuntasan belajar siswa dari data untuk melakukan perencanaan lanjutan pada siklus berikutnya.Penentuan persentase ketuntasan belajar siswa dihitung menggunakan rumusberikut.

$\mathrm{P}=\frac{\sum \text { Jumlah siswa yang tuntas belajar }}{\text { Jumlah siswa }}$

Hasil persentase tersebut dikategorikan berdasarkan criteria berikut.

Tabel 1.Kategori Tingkat Keberhasilan

\begin{tabular}{cl}
\hline Tingkat Keberhasilan $(\boldsymbol{\%})$ & \multicolumn{1}{c}{ Kategori } \\
\hline$\ldots>20$ & Sangatrendah \\
$20-39$ & Rendah \\
$40-59$ & Sedang \\
$60-79$ & Tinggi \\
$80<\ldots$ & Sangattinggi \\
\hline
\end{tabular}

Sumber: Budiman (2014) 


\section{JURNALILMIAH}

BINAEDUKASI

ISSN 1979-8598E-ISSN: 2655-8378

http://journal.binadarma.ac.id/index.php/jurnalbinaedukasi

Vol. 12, No. 2, Desember 2019, 31 -- 41

Setelah memeroleh data hasil belajar dan persentase ketuntasan belajar kemudian dideskripsikan dan ditarik kesimpulan berdasarkan hasil tersebut.

\section{HASIL DAN PEMBAHASAN}

Sesuai dengan rencana kesepakatan dengan guru yang mengajar mata pelajaran IPA kelas IV, penulis melakukan pengamatan di kelas IV pada hari Senin, tanggal 05 Agustus 2019 (pukul 09.30 s.d 10.05). Penulis mengamati secara cermat situasi dan kondisi peserta didik kelas IV yang dijadikan subjek penelitian. Selain pengamatan, penulis juga mengadakan tes awal (pretest). Tes awal tersebut diikuti oleh dua puluh peserta didik. Pada tes awal ini penulis memberikan sepuluh buah soal. Berdasarkan data hasil tes awal ditemukan hasil belajar peserta didik sebagai dampak dari proses pembelajaran dengan menggunakan model pembelajaran konvensional menunjukkan belum maksimalnya hasil belajar peserta didik pada mata pelajaran IPA khususnya materi Energi Alternatif.Berikut persentase ketuntasan belajar dari hasil pretes yang dilakukan oleh siswa.

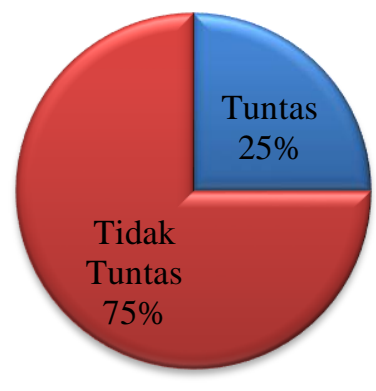

Gambar.1 Ketuntasan Belajar pada Pretes

Berdasarkan gambar 1di atas diketahui bahwa dari dua puluh siswa yang mengikuti pretes ternyata yang mencapai ketuntasan belajar hanya empat orang siswa atau $20 \%$, sedangkan enam belas orang siswa belum tuntas atau $80 \%$. Hasil tersebut belum sesuai dengan syarat mencapai ketuntasan belajar yaitu $\geq 75 \%$ dari jumlah peserta didik dalam satu kelas. Hal ini jelas menunjukkan bahwa sebagian besar peserta didik kelas IV belum menguasai materi Energi Alternatif pada mata pelajaran IPA. Berdasarkan hasil pretes tersebut maka dilanjutkan ke siklus I.

Pertemuan 1 pada siklus I dilaksanakan pada Rabu, 07 Agustus 2019 dengan alokasi waktu 2x35 menit. Berikut ini rincian kegiatan pembelajaran pertemuan 1 dengan Energi Alternatif. 


\section{JURNALILMIAH \\ BINAEDUKASI}

ISSN 1979-8598E-ISSN: 2655-8378

http://journal.binadarma.ac.id/index.php/jurnalbinaedukasi

Vol. 12, No. 2, Desember 2019, 31 -- 41

Tabel 2. Kegiatan Pembelajaran Pertemuan 1 (Siklus I)

\begin{tabular}{ll}
\hline No. & \multicolumn{1}{c}{ Kegiatan Pembelajaran } \\
\hline 1 & Kegiatan Pendahuluan \\
a. Guru mengkondisikan peserta didik agar siap mengikuti pelajaran \\
b. Guru mengajak siswa berdoa bersama \\
c. Guru mengecek kehadian peserta didik \\
d. Guru menyampaikan tujuan pembelajaran kepada peserta didik \\
e. Guru menyampaikan persepsi berupa tanya-jawab kepada peserta didik tentang \\
Knergi Alternatif \\
Kegiatan Inti \\
a. Guru menjelaskan materi EnergiAlternatif \\
b. Guru membagi kelompok peserta didik ke dalam 4 kelompok dengan jumlah \\
anggota 5 orang siswa setiap kelompok. \\
c. Guru membagikan lembar kerja kelompok kepada masing-masing kelompok \\
d. Guru meminta masing-masing perwakilan kelompok menuliskan hasil \\
jawabannya di papan tulis, dan dikoreksi bersama-sama \\
e. Guru meminta kelompok yang berhasil mengerjakan tugas dengan baik \\
menempelkan bintang untuk kelompoknya \\
Kegiatan Penutup a \\
a. Guru membimbing pesertadidik untuk menarik kesimpulan yang sudah dipelajari \\
b. Guru memberitahukan bahwa pada pertemuan selanjutnya akan diadakan kuis \\
c. Guru mengakhiri pembelajaran dengan mengucapkan salam.
\end{tabular}

Pertemuan 2 pada siklus I dilaksanakan pada hari Senin, tanggal 12 Agustus 2019 dengan alokasi waktu 2x35 menit. Berikut rincian kegiatan pembelajaran pertemuan 2, pada siklus I dengan Energi Alternatif.

Tabel 3. Kegiatan Pembelajaran Pertemuan 2 (Siklus I)

\begin{tabular}{ll}
\hline No. & \multicolumn{1}{c}{ Kegiatan Pembelajaran } \\
\hline 1 & Kegiatan Pendahuluan \\
a. Guru mengondisikan pesertadidik agar siap mengikuti pelajaran \\
b. Guru mengajak siswa berdoa bersama \\
c. Guru mengecek kehadiran pesertadidik \\
d. Guru menyampaikan tujuan pembelajaran kepada peserta didik \\
e. Guru menyampaikan persepsi berupa tanya-jawab kepada pesertadidik tentang Energi \\
Kegiatan Inti \\
a. Guru membagikan soal kuis individu \\
b. Guru berkelilingi mengawasi peserta didik \\
c. Guru meminta peserta didik bertukaran lembar jawaban untuk dikoreksi jika sudah \\
d. Gelesai \\
Kegiatan Penutup meminta peserta didik untuk menempelkan bintang pada nama yang tertulis di \\
a. Guru membimbing peserta didik untuk menarik kesimpulan yang sudah dipelajari \\
b. Guru memberitahukan materi untuk pertemuan selanjutnya \\
c. Guru mengakhiri pembelajaran dengan mengucapkan salam.
\end{tabular}

Setelah pertemuan 2, pada siklus I dilakukan postes.Nilai rata-rata yang diperoleh siswa pada hasil postes siklus I, nilai rata-rata sebesar 60,5. Dibandingkan dengan hasil pretes, hasil belajar peserta didik pada postes siklus I sudah mengalami peningkatan. 


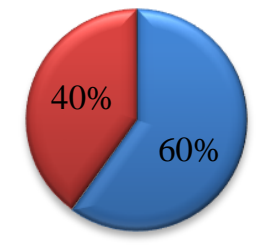

Gambar 2. Ketuntasan Hasil Belajar Siklus I

Kemudian, dilanjutkan ke tahap refleksi. Berdasarkan, hasil refleksi dengan hasil persentase ketuntasan $60 \%$ di kategori tinggi. Penulis dan guru bidang studi IPA kelas IV sepakat untuk melanjutkan penelitian ke siklus II untuk meningkatkan ketuntasan 90\%.

Siklus II dilaksanakan dalam 2 kali pertemuan. Pertemuan 1, siklus II dilaksanakan pada hari Rabu, tanggal 14 Agustus 2019 dan Senin, tanggal 19 Agustus 2019 dengan alokasi waktu 2 x 35 menit. Adapun materi yang akan diajarkan adalah mengulang materi yang telah diajarkan pada siklus I, yakni Energi Alternatif. Kegiatan yang dilakukan oleh penulis pada pertemuan 1 siklus II sama dengan siklus II.Pertemuan 2 pada siklus II dilaksanakan pada Senin,19 Agustus 2019. Langkah-langkah kegiatanpun sama dengan yang dilakukan di siklus I. Dari hasil postes siklus II diperoleh rata-rata kelas adalah 79,5 dengan ketuntasan belajar 90\% (18 peserta didik) dan 10\% (2 peserta didik) yang belum tuntas. Perhatikan baganberikut.

\section{$\square$ Tuntas $\square$ Tidak Tuntas}

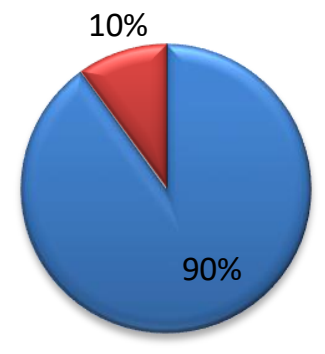

Gambar 3..Ketuntasan Hasil Belajar Siklus II

Berdasarkan persentase ketuntasan belajar dapat diketahui bahwa pada siklus II peserta didik kelas IV telah mencapai ketuntasan belajar dengan persentase sebesar 88,88\% sudah di atas ketuntasan minimum yang telah ditentukan. Dengan demikian, dapat dikatakan bahwa model pembelajaran kooperatif tipe Student Teams Achievement Division (STAD) mampu meningkatkan ketuntasan belajar peserta didik kelas IV di SD Negeri 05 


\section{JURNALILMIAH}

BINAEDUKASI

ISSN 1979-8598E-ISSN: 2655-8378

http://journal.binadarma.ac.id/index.php/jurnalbinaedukasi

Vol. 12, No. 2, Desember 2019, 31 -- 41

Rantau Alai. Dengan demikian siklus penelitian tindakan kelas dihentikan. Hasil belajar peserta didik mengalami peningkatan mulai dari pretes, postes siklus I, hingga postes siklus II. Untuk lebih jelasnya, dapat dilihat pada tabel di bawah ini.

Tabel 4. Hasil Tes Belajar Peserta Didik

\begin{tabular}{llcccr}
\hline No & \multicolumn{1}{c}{ Uraian } & Pretes & $\begin{array}{c}\text { Postes } \\
\text { Siklus I }\end{array}$ & $\begin{array}{c}\text { Postes } \\
\text { Siklus II }\end{array}$ & Keterangan \\
\hline 1 & Jumlah Peserta Tes & 20 & 20 & 20 & Tetap \\
2 & Nilai rata-rata peserta didik & 42,24 & 60,5 & 79,5 & Meningkat \\
3 & Jumlah peserta didik yang tuntas belajar & 4 & 12 & 18 & Meningkat \\
4 & $\begin{array}{l}\text { Jumlah peserta didik yang belum tuntas } \\
\text { belajar }\end{array}$ & 16 & 8 & 2 & Meningkat \\
5 & Presentase ketuntasan belajar & $20 \%$ & $60 \%$ & $90 \%$ & Meningkat \\
\hline
\end{tabular}

Dari tabel di atas dapat diketahui bahwa hasil belajar peserta didik selalu mengalami peningkatan mulai dari pretes, postes siklus I, hingga postes siklus II. Hal ini terbukti dari peningkatan nilai rata-rata peserta didik pada pretes sebesar 42,25 meningkat menjadi 60,5 (postes siklus I) dan mengalami peningkatan kembali sebanyak 79,5 (postes siklus II).

Selain itu, peningkatan hasil belajar peserta didik juga dapat dilihat dari ketuntasan belajar peserta didik. Hal ini terbukti dari hasil pretes, dari dua puluh peserta didik yang mengikuti tes hanya empat peserta didik atau $20 \%$ yang tuntas belajar. Kemudian meningkat pada postes siklus I dari dua puluh peserta didik yang mengikuti tes, peserta didik yang mencapai ketuntasan belajar sebanyak dua belas peserta didik atau 60\%. Kemudian, meningkat kembali pada Postes siklus II dari dua puluh peserta didik yang mengikuti tes, delapan belas peserta didik atau 90\% telah mencapai ketuntasan belajar. Dengan demikian, dapat disimpulkan bahwa penerapan model pembelajaran kooperatif tipe Student Teams Achievement Division (STAD) ini mampu meningkatkan hasili belajar IPA kelas IV SD Negeri 05 Rantau Alai.

Hal ini menunjukkan bahwa dengan berkelompok siswa dapat memaksimalkan kemampuannya untuk bekerja sama. Senada dengan pendapat yang dikemukakan Johnson dan Johnson (Isjoni, 2012), bahwa pembelajaran kooperatif adalah mengelompokkan siswa di dalam kelas ke dalam suatu kelompokkecil agar siswa dapat bekerjasamadengankemampuan maksimal yang mereka miliki dan mempelajari satu sama lain dalam kelompok tersebutdengan bekerja sama secara maksimal, hasil belajar siswa dapat meningkat. Pendapat serupa juga dibuktikan dari hasil Slavin (Rusman, 2011) yang menyatakan bahwa pembelajaran kooperatif dapat 
meningkatkanprestasi belajar siswa, meningkatkan hubungansosial, menumbuhkan sikap toleransi, menghargai pendapat orang lain, meningkatkan kemampuan berfikirkritis, meningkatkan kemampuan memecahkan masalah,serta mengintegrasikan pengetahuan dan pengalaman.

\section{SIMPULAN}

Berdasarkan penelitian yang telah dilakukan, dapat ditarik kesimpulan bahwa penerapan model pembelajaran kooperatif tipe Student Teams Achievement Division (STAD) pada mata pelajaran IPA dengan materi Energi Alternatif, terbukti dapat meningkatkanhasilbelajar peserta didik kelas IV SD Negeri 05 Rantau Alai. Pada siklus I, nilai rata-rata dan persentase yang diperoleh siswa masih belum maksimal, yaitu sebesar 60\%. Dari hasil pengamatan, peserta didik menyelesaikan tugas kelompok secara individual dan belum bisa bekerja sama dengan baik. Pada pelaksanaan siklus II, peserta didik sudah bisa bekerja sama dalam satu kelompok dengan baik dilihat dari nilai persentase kelompok yang meningkat. Hal ini dapat dilihat dari hasil siklus I ke siklus II yaitu dari persentase $60 \%$ meningkat menjadi $90 \%$ dengan kategori kelompok baik.

Selain itu dapat pula dilihat dari peningkatan skor tim yang didapatkan dari peningkatan skor individual. Pada siklus I,Tim A mendapatkan rata-rata13,75; Tim B mendapatkan rata-rata 22,5; Tim C mendapatkan rata-rata 14; dan Tim D mendapatkan rata-rata 13. Pada siklus 2, Tim A mendapatkan rata-rata 20; Tim B mendapatkan rata-rata 20,5; Tim C mendapatkan rata-rata 22; dan Tim D mendapatkan rata-rata 12,5.

Penerapanmodelpembelajaran Kooperatif Tipe Student Teams Achievement Division (STAD) dapat meningkatkan hasil belajar peserta didik kelas. Hasil tes juga mengalami peningkatan. Pada postes siklus I,nilai rata- rata peserta didik 60,5. Pada postes siklus II, nilai rata-rata peserta didik 79,5. Demikian juga mengalami peningkatan pada persentase ketuntasan sebesar 30\% , yaitu 60\% pada postes siklus 1 menjadi 90\% pada siklus II.

\section{DAFTAR PUSTAKA}

Aqib, Z. 2009. Penelitian Tindakan Kelas untuk SD, SLB dan TK. Bandung: Yrama Widya.

Budiman, Karjono, Samirah. 2014. Meningkatkan Aktivitas dan Hasil Belajar Matematika pada Materi Luas Bangun Datar dengan Menggunakan Model Pembelajaran Kooperative Tipe STAD Siswa Kelas VIB SD Tunas Harapan Bandar Lampung Tahun Pelajaran 2013/2014.Skripsi tidak Dipublikasikan.Universitas Lampung: Fakultas Keguruan dan Ilmu Pendidikan. 


\section{JURNALILMIAH}

BINAEDUKASI

ISSN 1979-8598E-ISSN: 2655-8378

http://journal.binadarma.ac.id/index.php/jurnalbinaedukasi

Vol. 12, No. 2, Desember 2019, 31 -- 41

Febriyanto, Galih. 2011. Upaya Meningkatkan Aktivitas Dan Hasil Belajar Siswa Dengan Menggunakan Metode Index Card Match Pada Mata Pelajaran Ipa Terhadap Siswa Kelas Iv Sd Negeri 2 Tanjungsari Rembang Tahun Ajaran 2011/2012. Skripsi tidak Dipublikasikan. Surakarta: Universitas Muhammadiyah Surakarta.

Isjoni. 2009. Pembelajaran Kooperatif Meningkatkan Kecerdasan Komunikasi Antar Peserta Didik. Yogyakarta: Pustaka Pelajar.

Nurjanah. 2016. Peningkatan Hasil Belajar IPA dengan Menerapkan Metode Inkuiri Siswa Kelas V SD Negeri 68 Kecamatan Bacukiki Kota Parepare. Publikasi Pendidikan. Makassar: Universitas Negeri Makassar.

Robert E, Slavin. 2015. Cooperative Learning: Teori, Riset dan Praktik. Bandung: Nusa Media.

Rusman. 2013. Model-Model Pembelajaran: Mengembangkan Profesionalisme Guru. Edisi ke2. Jakarta: PT Raja Grafindo Persada.

Shoimin, Aris. 2016. 68 Model Pembelajaran Inovatif dalam Kurikulum 2013.Yogyakarta: ArRuzz Media.

Soedarsono. 2001. Aplikasi Penelitian Tindakan Kelas. Jakarta: Direktorat Jendral Pendidikan Tinggi Departemen Pendidikan Nasional.

Arikunto, Suharsimi. 2010. Prosedur Penelitian Suatu Pendekatan Praktek. Jakarta: Rineka Cipta.

Sukardi. 2007. Metodologi Penelitian Pendidikan: Kompetensi dan Praktiknya. Jakarta: PT. Bumi Aksara.

Susanto, Ahmad. 2013. Teori Belajar dan Pembelajaran di Sekolah Dasar. Jakarta:Prenadamedia Group. 